\title{
Arterial eicosanoid production following chronic exposure to a periarterial haematoma
}

\author{
JD PICKARD, ${ }^{*}$ V WALKER, $†$ S PERRY, $¥$ PJ SMYTHE, $†$ S EASTWOOD, $\dagger$ R HUNT§
}

From the Wessex Neurological Centre* and University Departments of Chemical Pathology, $\uparrow$ and Surgery, $\ddagger$ and Department of Neuropathology, § Southampton General Hospital, Southampton, UK

SUMMARY Cisternal and lumbar cerebrospinal fluid obtained some days following a subarachnoid haemorrhage contains abnormally large quantities of various prostanoids; some may be partly the result of abnormal production by the cerebral arteries. The extra-arterial and intra-arterial production of 6 oxo $\mathrm{PGF}_{1 \alpha}$ (prostacyclin metabolite), $\mathrm{PGE}_{2}, \mathrm{PGF}_{2 \alpha}$ and $\mathrm{TXB}_{2}$ were measured in perfused rabbit common carotid arteries taken both from normal rabbits and from rabbits in which the arteries had been ensheathed by blood clot in vivo for 7 days using two techniques. Prostaglandin production by control arteries was highest during the first hour of perfusion but declined or increased marginally $\left(\mathrm{PGE}_{2}\right)$ during the succeeding three hours. Arteries exposed to a periarterial haematoma for 7 days produced prostaglandins at a high rate throughout the 4 hours of study, and there was a progressive and marked increase in $\mathrm{PGE}_{2}$ production. The disproportionate increase in the cerebral vasoconstrictor $\mathrm{PGE}_{2}$ may reflect the inflammatory response which occurred in the adventitia of the vessels. Increased prostanoid production by cerebral arteries probably does contribute to the increased levels in CSF after subarachnoid haemorrhage.

Although blood will induce immediate contraction of cerebral arteries in vitro, angiography in patients following subarachnoid haemorrhage has shown that cerebral vasospasm is seldom seen in tiie first 48 hours after a bleed and is maximal at around 7 days. The use of early CT scanning has revealed that vasospasm tends to develop in those arteries which have been enveloped in a significant periarterial haematoma. ${ }^{2}$ Hence some blood component is involved in the development of cerebral vasospasm, and this phenomenon seems to reflect an exaggerated contractile response to vasoactive agents released where clot and arterial wall are in close apposition. The prostaglandin hypothesis of cerebral vasospasm supposes that an excessive production intracranially of the cerebral vasoconstrictors Thromboxane $A_{2}$ (TXA $)$, prostaglandin (PG) $F_{2 \alpha}$, or $\mathrm{PGE}_{2}$, or defective synthesis of the vasodilator prostacyclin, might be implicated in the cerebrovas-

Address for reprint requests: Mr JD Pickard, Wessex Neurological Centre, Southampton General Hospital, Southampton SO9 4XY, UK

Received 19 December 1983

Accepted 30 January 1984. cular changes in subarachnoid haemorrhage (see ref 3 for review). In parallel studies of dogs and man it was found that subarachnoid haemorrhage results in a marked increase in $\mathrm{PGE}_{2}, \mathrm{PGF}_{2 \alpha}, 6$ oxo $\mathrm{PGF}_{1 \alpha}$ (the prostacyclin metabolite) but little $\mathrm{TXB}_{2}$ (the $\mathrm{TXA}_{2}$ metabolite) in lumbar and cisternal CSF examined 3 to 7 days after subarachnoid haemorrhage (see ref 4 for review of the literature). Proportionately, the increase in $\mathrm{PGE}_{2}$ was greatest in both species. Although prostanoid production by extravasated blood cells in the subarachnoid space undoubtedly accounted for some of the increase, this would not have explained the marked increase in $\mathrm{PGE}_{2}$ observed. It was suggested on the basis of in vitro synthesis results that some of this might derive from increased production by cerebral arteries.

The objects of the present investigation were to determine: (1) whether $\mathrm{PGE}_{2}, \mathrm{~F}_{2 \alpha}, 6$ oxo $F_{1 \alpha}$ and $\mathrm{TXB}_{2}$ diffuse outwards from arterial walls into a bathing fluid such as CSF; (2) how quickly an altered arterial production of these prostanoids is reflected in the bathing fluid; (3) whether the extra-arterial release of prostanoids is modified by ensheathing the artery with blood clot in vivo for 7 days, in an attempt to mimic events in subarachnoid haemorrhage. 


\section{Materials and methods}

Materials Standard prostaglandins ( $\mathrm{PG}) \mathrm{E}_{2}, 6$ oxo $\mathrm{F}_{1 \alpha}, \mathrm{F}_{2 \alpha}$ (tromethamine salt) and $\mathrm{TXB}_{2}$ were gifts from Dr John Pike, the Upjohn Co., Kalamazoo, Michigan, USA; ${ }^{3} \mathrm{H} \mathrm{PGE}_{2},{ }^{3} \mathrm{H} 6$ oxo $\mathrm{PGF}_{1 \alpha}$, and ${ }^{3} \mathrm{H} \mathrm{PGF}_{2 \alpha}$ were from the Radiochemical Centre, Amersham. ${ }^{3} \mathrm{H} \mathrm{TXB}_{2}$ was from New England Nuclear, Boston, Mass. USA. Antisera to $\mathrm{PGE}_{2}, \mathrm{TXB}_{2}$, and 6 oxo $\mathrm{PGF}_{1 \alpha}$ were from Institut Pasteur Production, Marnes-La Coquette, France. Antiserum to PGF $_{2 \alpha}$ was a gift from Dr Keith Hillier, University of Southampton, England. Indomethacin and Bovine Serum Albumin (Cohn Fraction V Powder) were from Sigma Chemical Co., St. Louis, USA. 14C indomethacin (13.5 Ci/mol) was a gift from Merck, Sharp \& Dohme. Krebs-Ringer-Bicarbonate buffer containing $1 \mathrm{mmol} / \mathrm{l}$ glutathione (KRB) was used in the perfusion studies (per litre: $\mathrm{NaCl} 7.24 \mathrm{~g}, \mathrm{KCl} 0.372 \mathrm{~g}, \mathrm{KH}_{2} \mathrm{PO}_{4} 0.163 \mathrm{~g}$, $\mathrm{NaHCO}_{3} 2 \cdot 184 \mathrm{~g}$, glucose $1.8 \mathrm{~g}$, MgSO4 $7 \mathrm{H}_{2} \mathrm{O} 0.32 \mathrm{~g}$, $\mathrm{CaCl}_{2} .2 \mathrm{H}_{2} \mathrm{O} 0.184 \mathrm{~g}$, glutathione $0.3072 \mathrm{~g} ; \mathrm{pH}$ adjusted to 7.4 after equilibrating with $95 \% \mathrm{O}_{2} / 5 \% \mathrm{CO}_{2}$ for $15 \mathrm{~min}$. $0.1 \mathrm{~mol} / \mathrm{l}$ phosphate buffer $\mathrm{pH} 7.5$ was used in the radioimmunoassays.

\section{Methods}

(1) Basal perfusion studies New Zealand white rabbits premedicated with droperidol $0.75 \mathrm{mg} / \mathrm{kg}$ im were anaesthetised with Althesin (0.9\% Alphaxolone + $0.3 \%$ Alphadolone $(1 \mathrm{ml} / \mathrm{kg} \mathrm{V} / \mathrm{V})$ and heparinised. $2-3 \mathrm{~cm}$ of both common carotid arteries were removed quickly. Each artery was cannulated at both ends and submerged in $4 \mathrm{ml}$ of Krebs- Ringer- Bicarbonate buffer pH 7.4 (KRB) gassed with $95 \% \mathrm{O}_{2} / 5 \% \mathrm{CO}_{2}$ at $37^{\circ}$ in an organ bath. Following a 10 min perfusion to wash out prostaglandins and free fatty acids, KRB containing $40 \mathrm{~g} / \mathrm{l}$ bovine serum albumin at $37^{\circ}$ was perfused continuously through the arterial lumen for 4 hours using a peristaltic pump, flow rate $1 \mathrm{ml} \mathrm{min}{ }^{-1}$, perfusing volume $4-4.5 \mathrm{ml}$. The perfusing and bathing buffers were collected and replaced by fresh buffer after each 60 min of perfusion. PGs and $\mathrm{TXB}_{2}$ in the fluids were extracted and assayed by radioimmunoassay. Slices were taken from the ends (before perfusion) and the middle (after perfusion) of the arteries, fixed in formalin and examined histologically. Albumin was added to the internal perfusing fluid to mimic physiological circumstances more closely. Preliminary experiments had shown that inclusion of albumin in the buffer did not influence arterial prostaglandin production significantly.

(2) Perfusion with indomethacin $10 \mu \mathrm{l}$ of a $15 \mathrm{mg} / \mathrm{ml}$ solution of indomethacin in ethanol was added to $10 \mathrm{ml}$ KRB containing $40 \mathrm{~g} / 1$ albumin, stirring vigorously. Eight arteries were perfused under basal conditions for $60 \mathrm{~min}$ as above. Buffer containing indomethacin $(15 \mu \mathrm{g} / \mathrm{ml})$ was perfused intra-arterially during the second $60 \mathrm{~min}$ perfusion period, the arteries being bathed externally with KRB. Perfusion with KRB + albumin (without indomethacin) was resumed for the 3 rd and 4 th hours. In one further experiment $0.3 \mu \mathrm{g} / \mathrm{ml}$ of ${ }^{14} \mathrm{C}$ indomethacin $\left(25 \times 10^{3} \mathrm{dpm}\right)$ was perfused intra-arterially, together with $15 \mu \mathrm{g} / \mathrm{ml}$ of the unlabelled compound. The labelled material recovered in the perfusates at the end of the 2nd, 3rd, and 4th hours of perfusion was measured by scintillation counting.
(3) Perfusion of arteries surrounded by blood clot for 7 days in vivo In a preliminary experiment, blood simply injected around a carotid artery had been entirely resorbed at the end of one week, leaving no residual haematoma and normal arterial histology. Two techniques were used to maintain clot in situ: (i) Four rabbits were anaesthetised and the common carotid arteries exposed. Fresh blood was injected around one artery and enclosed in a loose sheath of polyvinyl chloride to hold the clot in apposition to the arterial wall. The animals recovered. Seven days later the arteries were removed and perfused in vitro under "basal" conditions. Arteries from seven further rabbits were studied which had been surrounded by a polyvinyl chloride sheath without blood clot for 7 days. (ii) In order to avoid the need for polyvinyl chloride sheaths to contain the clot, five rabbits were dosed with the antifibrinolytic agent tranexamic acid (TEA) (500 mg orally daily) for 10 days. On the third day, the carotid arteries were exposed, blood injected around one artery, the other acting as a control, and the neck closed. Both arteries were removed 7 days later and perfused. Sections of the arteries were examined histologically

\section{Results}

PROSTAGLANDIN/TXB ${ }_{2}$ RELEASED FROM

ARTERIES PERFUSED UNDER BASAL CONDITIONS All the prostaglandins measured and $\mathrm{TXB}_{2}$ were released into both the intraluminal perfusing fluid and the extra-arterial bathing buffer (table 1). Production of $\mathrm{PGE}_{2 \alpha}, 6$ oxo $\mathrm{PGF}_{1 \alpha}$, and $\mathrm{TXB}_{2}$ was highest during the first hour but declined to lower levels during the succeeding 3 hours. Production of $\mathrm{PGF}_{2}$ was maintained at a more-or-less constant level throughout perfusion, although a small increase was apparent by the fourth hour.

Intraluminally the prostacyclin metabolite 6 oxo PGF $_{1 \alpha}$ was released in highest quantity (median $48.7 \mathrm{pg}$ per $\mathrm{mg}$ wet wt of artery in the first $60 \mathrm{~min}$ ), followed by $\mathrm{PGE}_{2}$ and $\mathrm{PGF}_{2 \alpha}$ in much lower and roughly similar amounts, with a small contribution from $\mathrm{TXB}_{2}$ (medians $7 \cdot 1,6 \cdot 5$, and $2 \cdot 4$ pg per mg wet wt respectively). Four arteries were examined histologically after 4 hours of perfusion, and all had lost around $80-95 \%$ of the endothelial cells. In two further arteries examined after 10 and $40 \mathrm{~min}$ of perfusion, the endothelium showed "occasional defects" and $25 \%$ loss respectively. Endothelial loss undoubtedly contributed to the decline of 6 oxo PGF $_{1_{\alpha}}$ noted after the first hour. 6 oxo $\mathrm{PGF}_{1_{\alpha}}$ was also the most abundant prostanoid in the extra arterial fluid (median $218.0 \mathrm{pg} / \mathrm{mg}$ wet wt of artery in the first $60 \mathrm{~min}$ ) followed by $\mathrm{PGE}_{2}$ (median $47.9 \mathrm{pg} / \mathrm{mg}$ wet wt) with smaller amounts of $\mathrm{PGF}_{2 \alpha}$ and $\mathrm{TXB}_{2}$ (medians 20.0 and $11.5 \mathrm{pg} / \mathrm{mg}$ wet wt respectively). An endothelial origin for the prostacyclin metabolite found extra-arterially was unlikely: in a study in which $3 \mathrm{H} 6$ oxo $\mathrm{PGF}_{1 \alpha}$ was perfused intra-arterially 
Table 1 Prostaglandin and thromboxane $B_{2}$ release from carotid arteries perfused under basal conditions

\begin{tabular}{|c|c|c|c|c|c|c|c|c|c|}
\hline \multicolumn{10}{|c|}{ Prostaglandins released (pg per $\mathrm{mg}$ wet wt of artery in $60 \mathrm{~min}$ ) } \\
\hline \multirow{2}{*}{$\begin{array}{l}\text { Collection } \\
\text { period }\end{array}$} & \multirow{2}{*}{$\begin{array}{l}\text { No. of } \\
\text { samples }\end{array}$} & \multicolumn{2}{|l|}{$P G F_{2 \alpha}$} & \multicolumn{2}{|l|}{$P G E_{2}$} & \multicolumn{2}{|c|}{$60 \times 0 P G F_{1 \alpha}$} & \multicolumn{2}{|l|}{$T X B_{2}$} \\
\hline & & Median & Ranget & Median & Range & Median & Range & Median & Range \\
\hline $\begin{array}{l}\text { Intra-arterial } \\
\text { 1st hour } \\
\text { 2nd } \\
\text { 3rd } \\
\text { 4th }\end{array}$ & $\begin{array}{r}18 \\
10 \\
10 \\
7\end{array}$ & $\begin{array}{l}6 \cdot 5 \\
4 \cdot 1 \\
6 \cdot 2 \\
5 \cdot 9\end{array}$ & $\begin{array}{l}2 \cdot 0-23 \cdot 7 \\
2 \cdot 2-8 \cdot 2 \\
1 \cdot 9-19 \cdot 5 \\
1 \cdot 7-7 \cdot 7\end{array}$ & $\begin{array}{l}7 \cdot 1 \\
5 \cdot 8 \\
7 \cdot 9 \\
9 \cdot 3\end{array}$ & $\begin{array}{l}1 \cdot 1-43 \cdot 3 \\
1 \cdot 0-26 \cdot 1 \\
3 \cdot 8-67 \cdot 5 \\
3 \cdot 4-36 \cdot 8\end{array}$ & $\begin{array}{l}48 \cdot 7 \\
20 \cdot 4 \\
28 \cdot 7 \\
25 \cdot 1\end{array}$ & $\begin{array}{l}7 \cdot 0-124 \cdot 1 \\
3 \cdot 3-53 \cdot 5 \\
7 \cdot 6-83 \cdot 5 \\
6 \cdot 2-47 \cdot 3\end{array}$ & $\begin{array}{l}2 \cdot 4 \\
2 \cdot 3 \\
1 \cdot 7^{*} \\
2 \cdot 2\end{array}$ & $\begin{array}{l}0.9-4 \cdot 0 \\
0.6-4 \cdot 2 \\
0.7-9 \cdot 2 \\
0.5-4 \cdot 2\end{array}$ \\
\hline $\begin{array}{l}\text { Extra-arterial } \\
1 \text { st hour } \\
\text { 2nd } \\
\text { 3rd } \\
4 \text { th }\end{array}$ & $\begin{array}{r}24 \\
13 \\
10 \\
7\end{array}$ & $\begin{array}{l}20.0 \\
17.5 \\
18.7 \\
16.0\end{array}$ & $\begin{array}{r}11 \cdot 1-74 \cdot 6 \\
9 \cdot 2-49 \cdot 1 \\
8 \cdot 7-36 \cdot 0 \\
7 \cdot 3-30 \cdot 6\end{array}$ & $\begin{array}{l}47 \cdot 9 \\
42 \cdot 6 \\
55 \cdot 2 \\
58 \cdot 1\end{array}$ & $\begin{array}{l}13 \cdot 7-116 \cdot 5 \\
12 \cdot 1-161 \cdot 3 \\
17 \cdot 4-151 \cdot 2 \\
21 \cdot 9-137 \cdot 0\end{array}$ & $\begin{array}{r}218.0 \\
140.1 \\
106.1 \\
83.7\end{array}$ & $\begin{array}{l}88 \cdot 4-420 \cdot 4 \\
57 \cdot 1-234 \cdot 8 \\
22 \cdot 6-231 \cdot 9 \\
22 \cdot 0-138 \cdot 0\end{array}$ & $\begin{array}{r}11 \cdot 5 \\
5 \cdot 5 \\
4 \cdot 0 \\
2.7\end{array}$ & $\begin{array}{l}5 \cdot 2-57 \cdot 6 \\
1 \cdot 6-17 \cdot 6 \\
1 \cdot 2-8 \cdot 4 \\
1 \cdot 0-5 \cdot 5\end{array}$ \\
\hline
\end{tabular}

*9 samples

tObserved range

Table 2 Effect of indomethacin perfusion on arterial release of prostaglandins and $T X B_{2}$

\begin{tabular}{|c|c|c|c|c|c|c|c|c|c|}
\hline \multicolumn{10}{|c|}{ Prostaglandins released (pg per $\mathrm{mg}$ wet wt of artery in $60 \mathrm{~min}$ ) } \\
\hline \multirow{2}{*}{$\begin{array}{l}\text { Collection } \\
\text { period }\end{array}$} & \multirow{2}{*}{$\begin{array}{l}\text { No. of } \\
\text { samples }\end{array}$} & \multicolumn{2}{|l|}{$P G F_{2 \alpha}$} & \multicolumn{2}{|l|}{$P G E_{2}$} & \multicolumn{2}{|c|}{$60 \times 0 P G F_{1 \alpha}$} & \multicolumn{2}{|l|}{$T X B_{2}$} \\
\hline & & Median & Range & Median & Range & Median & Range & Median & Range \\
\hline $\begin{array}{l}\text { Intra-arterial } \\
\text { 1st hour } \\
\text { 2nd } \dagger \\
\text { 3rd } \\
\text { 4th }\end{array}$ & $\begin{array}{l}8 \\
8 \\
7 \\
7\end{array}$ & $\begin{array}{l}5.5 \\
3.0 \\
2.1 \\
1.8\end{array}$ & $\begin{array}{l}2 \cdot 0-23 \cdot 7 \\
2 \cdot 0-11 \cdot 4 \\
1 \cdot 5-5 \cdot 4^{*} \\
1 \cdot 2-5 \cdot 0^{*}\end{array}$ & $\begin{array}{l}5.0 \\
6 \cdot 6 \\
3 \cdot 4 \\
2 \cdot 4\end{array}$ & $\begin{array}{l}1 \cdot 1-25 \cdot 2 \\
2 \cdot 1-29 \cdot 0 \\
1 \cdot 4-17 \cdot 9^{*} \\
1 \cdot 4-16 \cdot 2\end{array}$ & $\begin{array}{l}44.2 \\
19.4 \\
11.9 \\
11.3\end{array}$ & $\begin{array}{c}21 \cdot 0-124 \cdot 1 \\
13 \cdot 0-39 \cdot 1 \\
5 \cdot 2-11.9^{*} \\
4 \cdot 0-28 \cdot 5^{*}\end{array}$ & $\begin{array}{l}1 \cdot 54 \\
\text { Insuff. } \\
\quad " \\
"\end{array}$ & $\begin{array}{l}1 \cdot 2-2 \cdot 9 \\
- \\
-\end{array}$ \\
\hline $\begin{array}{l}\text { Extra-arterial } \\
\text { 1st hour } \\
\text { 2nd } \\
\text { 3rd } \\
\text { 4th }\end{array}$ & $\begin{array}{l}8 \\
8 \\
7 \\
7\end{array}$ & $\begin{array}{l}26 \cdot 7 \\
22 \cdot 3 \\
11 \cdot 4 \\
10 \cdot 5\end{array}$ & $\begin{array}{r}11 \cdot 1-49 \cdot 0 \\
10 \cdot 3-41 \cdot 4 \\
5 \cdot 1-26 \cdot 4 \\
3 \cdot 6-21 \cdot 1\end{array}$ & $\begin{array}{l}42 \cdot 6 \\
44 \cdot 6 \\
34 \cdot 0 \\
20 \cdot 7\end{array}$ & $\begin{array}{l}14 \cdot 6-116 \cdot 5 \\
21 \cdot 9-114 \cdot 5 \\
15 \cdot 9-103 \cdot 4 \\
12 \cdot 6-107 \cdot 6\end{array}$ & $\begin{array}{r}222.3 \\
117.4 \\
56.7 \\
59.6\end{array}$ & $\begin{array}{l}88 \cdot 6-333 \cdot 6 \\
60 \cdot 7-185 \cdot 0 \\
36 \cdot 6-103 \cdot 9 \\
15 \cdot 3-86 \cdot 0\end{array}$ & $\begin{array}{r}11.4 \\
3.5 \\
1.5 \\
1.4\end{array}$ & $\begin{array}{l}5 \cdot 2-34 \cdot 8 \\
2 \cdot 0-13 \cdot 2 \\
0.9-11 \cdot 3 \\
0.7-4 \cdot 8\end{array}$ \\
\hline
\end{tabular}

*Significantly lower values $(p<0.05)$ than samples collected from normal arteries basally during the corresponding collection period (table 1) (Mann Whitney U test)

During the second hour indomethacin was perfused intraluminally: conc. $15 \mu \mathrm{g}$ per $\mathrm{ml}$.

(two arteries), $3.0 \%$ and $1.9 \%$ of label was recovered from outside the artery in four hours, compared with $95.2 \%$ and $98.7 \%$ respectively from inside.

\section{EFFECTS OF INDOMETHACIN PERFUSION}

Eight arteries were perfused intraluminally during the second hour of study with indomethacin at a therapeutic concentration for man $(15 \mu \mathrm{g} / \mathrm{ml})$. The objective was to manipulate prostanoid production within the arterial wall, and to determine how closely the change was reflected in the external bathing buffer. Indomethacin decreases prostaglandin and $\mathrm{TXA}_{2}$ synthesis by inhibiting cyclo-oxygenase in the biosynthetic pathway. Because prostaglandin production by control arteries decreased progressively after the first hour (see above), results for indomethacin-perfused arteries must be compared with those of controls for the same collection period. Indomethacin caused a decrease in all intra- and extra-arterial prostanoids, but this was significant only for intra-arterially released $\mathrm{PGF}_{2 \alpha}, \mathrm{PGE}_{2}$, and 6 oxo PGF ${ }_{1 \alpha}$ (table 2). When ${ }^{14} \mathrm{C}$ indomethacin was infused with the unlabelled compound intraarterially (one artery), $\mathbf{9 7 . 8 \%}$ of the labelled material was recovered from intraluminal perfusates by the end of the fourth hour and only $0.7 \%$ extraarterially. Thus very little indomethacin penetrated through the arterial wall.

IN VITRO PROSTAGLANDIN/TXB RELEASE BY $_{2}$ ARTERIES WHICH WERE ENSHEATHED BY BLOOD CLOT IN VIVO FOR 7 DAYS

(i) Using a polyvinyl chloride sheath to hold blood clot in situ

This first method of maintaining clot adjacent to the arterial wall was employed in four animals. After 7 days the ensheathed arteries were removed and perfused in vitro. Prostaglandin production during the first hour was not increased in comparison to control 
Table 3 Prostaglandin and $T X B_{2}$ release from arteries which were ensheathed with blood clot for 7 days in vivo (with a cuff)

\begin{tabular}{|c|c|c|c|c|c|c|c|c|c|}
\hline \multicolumn{10}{|c|}{ Prostaglandins released (pg per $\mathrm{mg}$ wet wt of artery in $60 \mathrm{~min}$ ) } \\
\hline \multirow{2}{*}{$\begin{array}{l}\text { Collection } \\
\text { period }\end{array}$} & \multirow{2}{*}{$\begin{array}{l}\text { No. of } \\
\text { samples }\end{array}$} & \multicolumn{2}{|c|}{$P G F_{2 \alpha}$} & \multicolumn{2}{|l|}{$P G E_{2}$} & \multicolumn{2}{|c|}{$60 x o P G F_{1 \alpha}$} & \multicolumn{2}{|l|}{$T \boldsymbol{X B}_{2}$} \\
\hline & & Median & Range & Median & Range & Median & Range & Median & Range \\
\hline \multicolumn{10}{|l|}{ Intra-arterial } \\
\hline $\begin{array}{l}\text { 1st hour } \\
\text { 2nd } \\
\text { 3rd } \\
\text { 4th }\end{array}$ & $\begin{array}{l}4 \\
4 \\
4 \\
4\end{array}$ & $\begin{array}{l}2 \cdot 3 \\
2 \cdot 3 \\
3 \cdot 3 \\
6 \cdot 1\end{array}$ & $\begin{array}{l}2 \cdot 2-2 \cdot 8 \\
1 \cdot 1-3 \cdot 4 \\
1 \cdot 5-5 \cdot 3 \\
3 \cdot 8-9 \cdot 7\end{array}$ & $\begin{array}{r}5 \cdot 2 \\
10 \cdot 9 \\
27 \cdot 2 \\
62 \cdot 2\end{array}$ & $\begin{array}{c}3 \cdot 4-20 \cdot 6 \\
8 \cdot 5-13 \cdot 5 \\
15 \cdot 4-31 \cdot 7 \\
46 \cdot 7-188 \cdot 3\end{array}$ & $\begin{array}{l}17 \cdot 9 \\
16 \cdot 8 \\
14 \cdot 7 \\
43 \cdot 1\end{array}$ & $\begin{array}{l}3 \cdot 1-36 \cdot 2 \\
4 \cdot 6-22 \cdot 4 \\
6 \cdot 8-36 \cdot 6 \\
9 \cdot 4-56 \cdot 8\end{array}$ & $\begin{array}{l}1 \cdot 7 \\
1 \cdot 8 \\
1 \cdot 7 \\
2 \cdot 6\end{array}$ & $\begin{array}{l}1 \cdot 2-2 \cdot 7 \\
1 \cdot 3-4 \cdot 4 \\
1 \cdot 1-5 \cdot 8 \\
1 \cdot 6-12 \cdot 4\end{array}$ \\
\hline \multicolumn{10}{|l|}{ Extra-arterial } \\
\hline $\begin{array}{l}\text { 1st hour } \\
\text { 2nd } \\
\text { 3rd } \\
4 \text { th } \\
\end{array}$ & $\begin{array}{l}4 \\
4 \\
4 \\
4\end{array}$ & $\begin{array}{l}12 \cdot 2 \\
11 \cdot 2 \\
18 \cdot 1 \\
27 \cdot 7\end{array}$ & $\begin{array}{r}10 \cdot 1-16 \cdot 0 \\
5 \cdot 3-21 \cdot 7 \\
12 \cdot 7-31 \cdot 5 \\
26 \cdot 4-49 \cdot 4^{*}\end{array}$ & $\begin{array}{r}79 \cdot 3 \\
141 \cdot 8 \\
320 \cdot 4 \\
524 \cdot 9\end{array}$ & $\begin{array}{c}38 \cdot 5-1444 \cdot 8 \\
54 \cdot 4-285 \cdot 0 \\
183 \cdot 1-1097 \cdot 1 \dagger \\
244 \cdot 4-987 \cdot 5 \dagger\end{array}$ & $\begin{array}{r}163 \cdot 1 \\
86 \cdot 5 \\
179 \cdot 1 \\
286 \cdot 3\end{array}$ & $\begin{array}{l}20 \cdot 9-288 \cdot 6 \\
27 \cdot 2-220 \cdot 5 \\
23 \cdot 9-258 \cdot 5 \\
37 \cdot 8-408 \cdot 5\end{array}$ & $\begin{array}{l}22 \cdot 6 \\
12 \cdot 7 \\
16 \cdot 2 \\
35 \cdot 0\end{array}$ & $\begin{array}{c}14 \cdot 9-28 \cdot 2 \\
6 \cdot 2-39 \cdot 3^{*} \\
12 \cdot 9-68 \cdot 5 \dagger \\
19 \cdot 2-144.4 \dagger\end{array}$ \\
\hline
\end{tabular}

* and +Significantly higher than samples collected from normal arteries during the corresponding collection periods:

* $p<0.05$; $t p<0.01$ (Mann Whitney U test)

Table 4 Prostaglandin and Thromboxane $B_{2}$ release from 5 carotid arteries ensheathed by blood clot for 7 days (TEA model) compare with release from arteries surrounded by polyvinyl chloride cuff clot, or polyvinyl chloride cuff only

\begin{tabular}{|c|c|c|c|c|c|c|c|c|c|c|c|c|}
\hline \multicolumn{13}{|c|}{ Prostaglandins released (pg per wet wt of artery in 60 min) } \\
\hline \multirow{2}{*}{$\begin{array}{l}\text { Collection } \\
\text { period }\end{array}$} & \multicolumn{2}{|l|}{$P G F_{2 \alpha}$} & \multirow[b]{2}{*}{$\begin{array}{l}\text { Cuffy } \\
\text { only }\end{array}$} & \multirow{2}{*}{$\frac{P G E_{2}}{T E A}$} & \multirow[b]{2}{*}{$C u f f+C l o t$} & \multirow[b]{2}{*}{$\begin{array}{l}\text { Cuff } \\
\text { only }\end{array}$} & \multicolumn{3}{|l|}{6 oxo $P G F_{1 \alpha}$} & \multicolumn{3}{|l|}{$T X B_{2}$} \\
\hline & $T E A+$ Clot $^{*}$ & $+C u f f+C l o t$ & & & & & $T E A$ & $C u f f+C l o t$ & $\begin{array}{l}\text { Cuff } \\
\text { only }\end{array}$ & $T E A$ & $C u f f+C l o t$ & $\begin{array}{l}\text { Cuff } \\
\text { only }\end{array}$ \\
\hline \multicolumn{13}{|l|}{ Intra-arterial } \\
\hline 1st hour & $\begin{array}{l}3 \cdot 9 \\
2 \cdot 2-14 \cdot 0\end{array}$ & $2 \cdot 3$ & $2 \cdot 9$ & $\begin{array}{l}4 \cdot 7 \\
1 \cdot 5-15 \cdot 7\end{array}$ & $5 \cdot 2$ & $5 \cdot 2$ & $\begin{array}{l}64 \cdot 1 \\
23 \cdot 2-214 \cdot 9\end{array}$ & $17 \cdot 9$ & $42 \cdot 4$ & $\begin{array}{l}2 \cdot 9 \\
1 \cdot 2-7 \cdot 4\end{array}$ & 1.7 & \\
\hline 2nd & $\begin{array}{l}4 \cdot 6 \\
3 \cdot 4-8 \cdot 5\end{array}$ & $2 \cdot 3$ & $3 \cdot 1$ & $\begin{array}{l}10.9 \\
6 \cdot 3-16 \cdot 6\end{array}$ & $10-9$ & 19.6 & $\begin{array}{l}72.6 \\
45 \cdot 9-132.9\end{array}$ & 16.8 & $45 \cdot 2$ & $\begin{array}{l}3.0 \\
1 \cdot 3-6.2\end{array}$ & $1 \cdot 8$ & \\
\hline 3rd & $\begin{array}{l}4 \cdot 7 \\
2 \cdot 6-8 \cdot 0\end{array}$ & $3 \cdot 3$ & $4 \cdot 7$ & $\begin{array}{l}13 \cdot 5 \\
7 \cdot 2-20.3\end{array}$ & $27 \cdot 2$ & $21 \cdot 7$ & $\begin{array}{l}88 \cdot 6 \\
21 \cdot 1-101 \cdot 7\end{array}$ & $14 \cdot 7$ & $74 \cdot 9$ & $\begin{array}{l}2.5 \\
1.8-5.6\end{array}$ & $1 \cdot 7$ & \\
\hline 4th & $\begin{array}{l}6 \cdot 7 \\
3 \cdot 2-9 \cdot 3\end{array}$ & 6.1 & $4 \cdot 9$ & $\begin{array}{r}24 \cdot 1 \\
7 \cdot 5-33 \cdot 9\end{array}$ & $62 \cdot 2$ & $31 \cdot 6$ & $\begin{array}{r}105 \cdot 7 \\
39 \cdot 2-212 \cdot 0\end{array}$ & $43 \cdot 1$ & 73.7 & $1 \cdot 3-6 \cdot 8$ & $2 \cdot 6$ & $2 \cdot \overline{9}$ \\
\hline \multicolumn{13}{|l|}{ Extra-arterial } \\
\hline 1st hour & $\begin{array}{l}24 \cdot 4 \\
16 \cdot 3-75 \cdot 3\end{array}$ & $12 \cdot 2$ & $24 \cdot 2$ & $\begin{array}{l}52 \cdot 3 \\
21 \cdot 0-169 \cdot 4\end{array}$ & $79 \cdot 3$ & 140.5 & $\begin{array}{l}470-3 \\
270-4-1656.9\end{array}$ & $163 \cdot 1$ & $335 \cdot 0$ & $\begin{array}{l}47 \cdot 1 \\
22 \cdot 3-148 \cdot 8\end{array}$ & $22 \cdot 6$ & $41 \cdot 2$ \\
\hline 2nd & $\begin{array}{l}22 \cdot 6 \\
14 \cdot 2-69 \cdot 3\end{array}$ & $11 \cdot 2$ & $28 \cdot 1$ & $\begin{array}{l}87.7 \\
34 \cdot 5-214.9\end{array}$ & $141 \cdot 8$ & $417 \cdot 3$ & $\begin{array}{l}285 \cdot 1 \\
214 \cdot 2-1140 \cdot 2\end{array}$ & 86.5 & $430-8$ & $\begin{array}{l}26.9 \\
16.7-130-4\end{array}$ & $12 \cdot 7$ & $66 \cdot 8$ \\
\hline 3rd & $\begin{array}{l}23 \cdot 3 \\
14 \cdot 1-77 \cdot 1\end{array}$ & $18 \cdot 1$ & 33.9 & $\begin{array}{l}111 \cdot 5 \\
50.8-320.0\end{array}$ & 320.4 & $430-3$ & $\begin{array}{l}280 \cdot 3 \\
235 \cdot 3-1072 \cdot 7\end{array}$ & $179 \cdot 1$ & $409 \cdot 2$ & $\begin{array}{l}24 \cdot 5 \\
14 \cdot 7-150 \cdot 9\end{array}$ & $16 \cdot 2$ & $75 \cdot 0$ \\
\hline 4th & $\begin{array}{l}30 \cdot 0 \\
15 \cdot 7-55 \cdot 1\end{array}$ & $27 \cdot 7$ & $37 \cdot 8$ & $\begin{array}{r}174 \cdot 2 \\
63 \cdot 8-286 \cdot 3\end{array}$ & $524 \cdot 9$ & $647 \cdot 3$ & $\begin{array}{l}252 \cdot 1 \\
190 \cdot 7-1430-6\end{array}$ & $286 \cdot 3$ & $426 \cdot 1$ & $13 \cdot 5-88 \cdot 2$ & $35 \cdot 0$ & $45 \cdot 2$ \\
\hline
\end{tabular}

*Median and range for 5 arteries

†Median for 4 arteries (cuff + clot) or 7 arteries (cuff only)

arteries (tables 3 and 1). Whereas prostaglandin production by the controls decreased during perfusion $\left(\mathrm{PGF}_{2 \alpha}, 6\right.$ oxo $\mathrm{PGF}_{1 \alpha}$ and $\mathrm{TXB}_{2}$ ) or increased only marginally $\left(\mathrm{PGE}_{2}\right)$, a progressive increase of all prostaglandins was observed for the arteries with clot, both intra- and extra-arterially. The most dramatic increase was in $\mathrm{PGE}_{2}$ production: by the 4th hour the median concentration intra-luminally was twelve times higher than in the first, and $\mathrm{PGE}_{2}$ production was significantly greater than that of control arteries ( $p<0.01$ Mann Whitney $U$ test). A similar progressive increase occurred in $\mathrm{PGE}_{2}$ release extra-arterially, to values significantly higher than those of control arteries $(p<0 \cdot 01)$. By the 4th hour the median value for $\mathrm{PGE}_{2}$ showed a nine-fold increase above that for normal arteries. Extraarterial release of $\mathrm{TXB}_{2}$ and of $\mathrm{PGF}_{2 \alpha}$ was also significantly increased above normal $(\mathrm{p}<0.01$ and $\mathrm{p}<0.05$ respectively) but the production achieved was considerably less than that for $\mathrm{PGE}_{2}$ (4th Hour medians $35.0\left(\mathrm{TXB}_{2}\right), 27.7\left(\mathrm{PGF}_{2 \alpha}\right)$ and 524.9 $\left(\mathrm{PGE}_{2}\right) \mathrm{pg}$ per $\mathrm{mg}$ wet wt of artery $\mathrm{h}^{-1}$ ). Production of 6 oxo PGF ${ }_{1 \alpha}$ increased during perfusion but not significantly.

When examined histologically, a marked inflammatory response was observed in the periadventitia of arteries surrounded by clot and polyvinyl chloride sheath. Numerous macophages were pres- 
ent together with some red blood cells. It was probable that a large part of the inflammatory response was attributable to the presence of the sheath rather than to trapped blood clot. Seven arteries were studied without entrapped blood clot. There was variation in the individual arterial responses, but overall prostaglandin production increased during perfusion in vitro, and the responses were not significantly different from those of arteries with polyvinyl chloride sheaths and clot. Again the most dramatic increase was in $\mathrm{PGE}_{2}$ production, and there was a significant increase in $\operatorname{TXB}_{2}(\mathrm{p}<0.01)$. The arteries were markedly inflamed.

(ii) Using antifibrinolytic treatment (TEA) to maintain the clot in situ

An alternative method of maintaining clot close to the arteries for 7 days was sought which avoided the introduction of foreign material. In some preliminary experiments (to be reported in detail elsewhere) this proved to be possible by treating the rabbits with the anti-fibrinolytic agent TEA (see methods). At the time of sacrifice 7 days after injecting blood into the neck, the carotid artery was thickened. Microscopically an inflammatory response was observed in the adventitia with macrophages, but this was less gross than in the case of polyvinyl chloride-ensheathed arteries. Release of prostanoids increased throughout the 4 hours of in vitro perfusion, and production was significantly increased in comparison to the paired control arteries. The response was less exaggerated than that observed with the cuffed arteries (table 4).

\section{Discussion}

This study has shown that prostaglandins and thromboxane do diffuse out from the rabbit common carotid arteries into extra-arterial bathing fluid under basal conditions of perfusion in vitro. 6 oxo $\mathrm{PGF}_{1 \alpha}$ was the most abundant, followed by $\mathrm{PGE}_{2}$. Since hardly any ${ }^{3} \mathrm{H} 6$ oxo $\mathrm{PGF}_{1 \alpha}$ perfused intraluminally diffused through the arterial wall, it can be concluded that the large quantities of this metabolite found extra-arterially derived from prostacyclin production in the outer layers of the artery, and not from the endothelial lining. Moncada et al $^{5}$ demonstrated that although the ability to produce prostacyclin is greatest at the intimal surface of the rabbit aorta, the smooth muscle layer also produces a substantial amount. Medial smooth muscle cells in tissue culture produce significant quantities of prostacyclin $^{67}$ together with $\mathrm{PGE}_{2}$ and $\mathrm{PGF}_{2 \alpha} .^{6}$ Thromboxane synthesis has been reported for human umbilical artery ${ }^{8}$ and rabbit pulmonary artery. ${ }^{9}$ The extra-arterial PGs detectable in our studies probably derive mainly from cells of the outer layers of the arterial wall, and in the light of current knowledge are likely to have been produced mostly by cells of the tunica media.

When indomethacin at a therapeutic concentration was perfused through arteries for 60 minutes, the extra-arterial release of all the prostanoids during the following 2 hours fell below that of control arteries, although the fall was not statistically significant. A more striking decrease was observed in the intra-arterial levels. The rabbit common carotid artery has a thick wall, and it is probable that the concentrations of indomethacin achieved in the outer layers of the arteries were too low to effect significant inhibition of prostanoid synthesis there. We found that minimal amounts of (radiolabelled) indomethacin permeated right through the wall into the extra-arterial fluid. These experiments demonstrate that changes in prostaglandin production in the outer arterial layers will be reflected in the prostanoid concentrations of a bathing fluid.

A prime reason for embarking on this study was to discover whether prostanoid production and release by arteries chronically enveloped by blood clot is altered. Our initial findings with the polyvinyl chloride model were exciting in that they demonstrated a progressive increase in prostaglandin production throughout 4 hours of perfusion in vitro, with a very exaggerated increase in $\mathrm{PGE}_{2}$. However in studies using a polyvinyl chloride cuff only without entrapped blood, very similar findings emerged, and it seems that much of the increased production must be attributed to the presence of the cuff around the artery in vivo. This induced a marked inflammatory response whether clot was present or absent. This criticism cannot be lodged against our other model using TEA. Although our observations are still preliminary, they show that prostaglandin production by the arteries was increased in much the same way as in the polyvinyl chloride model, but to a less marked degree. The arteries were inflamed, and further experiments with electron-microscopy are underway.

It seems likely that the exaggerated response must reflect in some way the inflammatory reaction in the arterial wall. Remarkably similar observations have been reported for a perfused hydronephrotic kidney model in the rabbit. Nishikawa et al ${ }^{10}$ found that unilateral ureteric obstruction for 3 days resulted in a marked facilitation of $\mathrm{PGE}_{2}$ release from an isolated perfused rabbit kidney basally, and in response to the vasoactive peptides bradykinin and angiotensin II. In addition, the perfused hydronephrotic kidney, unlike the normal kidney, has been shown to release $\mathrm{TXA}_{2} ; \mathrm{TX}$ biosynthesis has been "unmasked" in other models of renal damage in the 
rabbit (for review see" ${ }^{11}$. Recently, Okegawa et al ${ }^{11}$ confirmed an enhanced release of $\mathrm{PGE}_{2}$ and $\mathrm{TXA}_{2}$ by the isolated perfused rabbit hydronephrotic kidney in response to bradykinin, and observed a sustained release in response to endotoxin. The responses were reduced 3-10 days after reversing the ureteric obstruction. Histologically, proliferation of fibroblast-like cells was observed in the cortex of the kidney together with mononuclear cells. With relief of obstruction, the monocytes decreased but not the fibroblasts. This group therefore concluded that the mononuclear cells had a critical involvement in the exaggerated arachidonic acid metabolism, and queried whether the close contact which they observed between mononuclear cells and the processes of cortical fibroblasts might have important metabolic consequences.

There are at least three ways in which inflammatory cell infiltration, particularly of monocytes/ macrophages, could account for the observed increases in $\mathrm{PGE}_{2}$ and $\mathrm{TXB}_{2}$. Macrophages themselves might be the source. These cells synthesise PGE $_{2}$, TXA $_{2}$ and prostacyclin, ${ }^{12-14}$ and $\mathrm{PGE}_{2}$ is a major arachidonic acid metabolite of activated macrophages. ${ }^{15}$ In our own preliminary studies (unpublished) incubated monocytes isolated from normal whole blood produced $\mathrm{PGE}_{2}$ and $\mathrm{TXB}_{2}$ in roughly similar amount with some, but much less, $\mathrm{PGF}_{2 \alpha}$ and 6 oxo PGF $_{1 \alpha}$. Activation of macrophages by endotoxin" or by "handling" of the inflamed tissue in vitro (present experiments) might have stimulated increased $\mathrm{PGE}_{2}$ and $\mathrm{TXB}_{2}$ release. There are two points against this being the whole mechanism for the changes observed here however: first the levels of $\mathrm{PGE}_{2}$ greatly exceeded those of TXA $\mathrm{T}_{2}$. Secondly a significant increase in intraluminal $\mathrm{PGE}_{2}$ but not $\mathrm{TXB}_{2}$ occurred, and it is difficult to relate this finding to macrophage production directly.

A second possibility is that lysosomal proteases or perhaps highly reactive oxygen-free radicals released from activated macrophages ${ }^{16}$ may have damaged the membranes of adjacent arterial smooth muscle cells. Membrane damage is known to increase arachidonic acid liberation from membrane phospholipids and, by increasing substrate availability, to increase prostaglandin production. This explanation could readily account for exaggerated release of $\mathrm{PGE}_{2}$ and $\mathrm{TXB}_{2}$ which are both products of normal medial smooth muscle cells.

The third possibility is that upon activation, macrophages release a factor which stimulates $\mathrm{PGE}_{2}$ production by adjacent connective tissue cells. Recent studies support the concept that products of lymphocytes and monocytes play a role in connective tissue cell activation. There have been several reports that conditioned media obtained from adherent monocytes stimulate fibroblast and/or synovial cell production of PGE $_{2}$ markedly (50-200 fold). ${ }^{11}{ }^{17}$ Nolan et al ${ }^{18}$ observed that a "proteinaceous" factor in medium from activated macrophages stimulated $\mathrm{PGE}_{2}$ production by chondrocytes, and (perhaps relevant to the present observations), that stimulation was detectable after a 4 hour exposure to the factor and was maximal at around 8 hours.

Do the observations from this study have any relevance to the cerebrovascular disturbances after subarachnoid haemorrhage? Because of practical considerations it was necessary to work with a large conducting artery, and it would be unwise to speculate too far until it has been shown that arteries from the base of the brain show similar behaviour in our experiments. It does seem however that prostaglandins produced in the outer arterial layers could contribute to the "pool" of these agents in the CSF. From our own observations (unpublished), on CSF collected from patients with a variety of intracranial pathology, there seems little doubt that CSF circulating in the subarachnoid space has a higher prostaglandin content than that secreted into the ventricles. Blood vessels crossing the subarachnoid space could well be one source of the "added" prostanoids, and the results of the indomethacin experiments indicate that changes in vascular production are likely to be reflected in altered CSF levels. This fits with some preliminary observations in dogs $^{4}$ in which a marked fall in prostaglandins in cisternal CSF occurred within 30 min of intravenous injection of indomethacin. In view of the speed of the response, a decrease in vascular production in relatively thin walled vessels seemed likely.

Against this background, our observation of a disproportionate increase in $\mathrm{PGE}_{2}$ in CSF after subarachnoid haemorrhage could well reflect increased production by cerebral arteries as we have suggested. Furthermore the experiments described here indicate that such an increase might result from an inflammatory reaction in the walls of those arteries enveloped by blood clot. The timing of vasospasm in man parallels closely the clearance of red cells from CSF, mainly by lysis with subsequent phagocytosis. ${ }^{19}$ Post-mortem studies in man have revealed that where death occurs at least three weeks after subarachnoid haemorrhage, there may be subendothelial cellular infiltration with lymphocytes and macrophages followed by subendothelial fibrosis located in the segment of arteries formerly shown to be in spasm on angiography. Where death occurs earlier, there may be evidence only of some inflammatory changes within the adventitia and possible some necrosis within the tunica media. Controversy has arisen over whether such structural changes are reproducible in animals or not. A consensus is 
emerging that simple cisternal instillation of blood does not produce histological change at least up to one week, unlike rupture of an artery ${ }^{20-21}$ except for the presence of macrophages and red cells in the adventitia.

It has been proposed ${ }^{22}$ that the increased thromboxane production of the rabbit hydronephrotic kidney (see above) contributes to renal vasoconstriction and the reduced glomerular filtration rate that occurs with hydronephrosis. Perhaps an exaggerated release of the cerebral vasoconstrictors $\mathrm{PGE}_{2}$ and $\mathrm{TXA}_{2}$ in and around the walls of large arteries ensheathed in blood coagulum similarly contribute to the vasospasm after subarachnoid haemorrhage.

This work was supported by Action Research. Our preliminary findings have been presented to the Medical Research Society, July 1983 (Clinical Science 1983;65:68p).

\section{References}

' Fisher CM, Kistler JP, Davis JM. Relation of cerebral vasospasm to subarachnoid haemorrhage visualised by computerized tomographic scanning. Neurosurgery 1980; 6:1-9.

${ }^{2}$ Bell BA, Kendall BE, Symon L. Computerized tomography in aneurysmal subarachnoid haemorrhage. $J$ Neurol Neurosurg Psychiatry 1980;43:522-4.

${ }^{3}$ Pickard JD. Role of prostaglandins and arachidonic acid derivatives in the coupling of cerebral blood flow to cerebral metabolism. J Cerebral Blood Flow and Metabolism 1981;1:361-384.

${ }^{4}$ Walker V, Pickard JD, Smythe PJ, Eastwood S, Perry S. Effects of subarachnoid haemorrhage on intracranial prostaglandins. J Neurol Neurosurg Psychiatry 1983;46:119-25.

${ }^{5}$ Moncada S, Herman AG, Higgs EA and Vane JR. Differential formation of prostacyclin (PGX or $\mathrm{PGI}_{2}$ ) by layers of the arterial wall. An explanation for the anti-thrombotic properties of vascular endothelium. Thromb Res 1977;11:323-44.

- Baenziger NL, Becherer PR, and Majerus PW. Characterization of prostacyclin synthesis in cultured human arterial smooth muscle cells, venous endothelial cells, and skin fibroblasts. Cell 1979;16:967-74.

${ }^{7}$ Larrue J, Leroux C, Daret D, and Bricaud H. Decreased prostaglandin production in cultured smooth muscle cells from atherosclerotic rabbit aorta. Biochem Biophys Acta 1982;710:257-63.

${ }^{8}$ Tuvemo T, Strandberg K, Hamberg M, Samuelsson B. Maintenance of the tone of the human umbilical artery by prostaglandin and thromboxane formation. In: Samuelsson B, Paoletti R. eds. Advances in Pros- taglandin and Thromboxane Research I: Raven Press N. York. 1976;425-8.

${ }^{9}$ Saltman P, Salmon JA, Moncada S. Prostacyclin and thromboxane $A_{2}$ synthesis by rabbit pulmonary artery. $J$ Pharmac Exp Ther 1980;215:240-7.

${ }^{10}$ Nishikawa K, Morrison A, Needleman P. Exaggerated prostaglandin biosynthesis and its influence on renal resistance in the isolated hydronephrotic rabbit kidney. J Clin Invest 1977;59:1143-50.

"Okegawa T, Jonas PE, De Schryver K, Kawasaki A, Needleman P. Metabolic and cellular alterations underlying the exaggerated renal prostaglandin and thromboxane synthesis in ureter obstruction in rabbits. J Clin Invest 1983;71:81-90.

12 Humes JL, Sadowski S, Galavage M, et al. Evidence for two sources of arachidonic acid for oxidative metabolism by mouse peritoneal macrophages. $J$ Biol Chem 1982; 257: 1581-94.

${ }^{13}$ Hsueh W, Kuhn C, Needleman P. Relationship of prostaglandin secretion by rabbit alveolar macrophages to phagocytosis and lysosomal enzyme release. Biochem J 1979;184:345-54.

${ }^{14}$ Kunkel SL, Kaercher K, Plewa M, Fantone JC, Ward PA. Production of cyclo oxygenase products and superoxide anion by macrophages in response to chemotactic factors. Prostaglandins 1982;24:789-99.

is Snider ME, Fertel R, Zwilling BS. Production of arachidonic acid metabolites by operationally defined macrophage subsets. Prostaglandins 1983;25:491501.

${ }^{16}$ Fantone JC, Ward PA. Role of oxygen-derived free radicals and metabolites in leukocyte-dependent inflammatory reactions. Am J Pathol 1982;107:395418.

${ }^{17}$ Korn JH. Fibroblast prostaglandin $E_{2}$ synthesis. Persistence of an abnormal phenotype after short-term exposure to mononuclear cell products. J Clin Invest 1983;71:1240-46.

${ }^{18}$ Nolan JC, Pickett W, English K, Oronsky AL, Kerwar SS. Stimulation of prostaglandin $\mathrm{E}_{2}$ synthesis in chondrocytes by a factor derived from activated macrophages. Prostaglandins 1982;24:433-49.

${ }^{19}$ Laurent JP. Subarachnoid haemorrhage. In: J.H. Wood ed. Neurobiology of Cerebrospinal Fluid I Plenum Press N. York and London 1980;279-86.

${ }^{20}$ Clower BR, Smith RR, Haining JL, Lockard J. Constrictive endarteropathy following experimental subarachnoid haemorrhage. Stroke 1981;12:501-8.

${ }^{21}$ Pickard JD, and Walker V. Current concepts of the role of prostaglandins and other eicosanoids in acute cerebrovascular disease. In: MacKenzie ET, ed. Neurotransmitters and the Cerebral Circulation. New York Raven Press 1984

${ }^{22}$ Yarger WE, Schoken DD, Harris RH. Obstructive nephropathy in the rat. Possible roles for the renin-angiotensin system, prostaglandins, and thromboxanes in post-obstructive renal function. $J$ Clin Invest 1980;65:400-12. 